\title{
Changes in discharge and solute dynamics between hillslope and valley-bottom intermittent streams
}

\author{
S. Bernal ${ }^{1}$ and F. Sabater ${ }^{2}$ \\ ${ }^{1}$ Biogeodynamics and Biodiversity Group, Center for Advanced Studies of Blanes (CEAB-CSIC), \\ Accés a la Cala St. Francesc 14, 17300 Blanes, Girona, Spain \\ ${ }^{2}$ Department of Ecology, Faculty of Biology, University of Barcelona, Diagonal 645, 08028 Barcelona, Spain \\ Correspondence to: S. Bernal (sbernal@ceab.csic.es)
}

Received: 4 October 2011 - Published in Hydrol. Earth Syst. Sci. Discuss.: 27 October 2011

Revised: 18 April 2012 - Accepted: 14 May 2012 - Published: 4 June 2012

\begin{abstract}
To gain understanding on how alluvial zones modify water and nutrient export from semiarid catchments, we compared monthly discharge as well as stream chloride, carbon, and nitrogen dynamics between a hillslope catchment and a valley-bottom catchment with a well-developed alluvium. Stream water and solute fluxes from the hillslope and valley-bottom catchments showed contrasting patterns between hydrological transitions and wet periods, especially for bio-reactive solutes. During transition periods, stream water export decreased $>40 \%$ between the hillslope and the valley bottom coinciding with the prevalence of streamto-aquifer fluxes at the alluvial zone. In contrast, stream water export increased by $20-70 \%$ between the hillslope and valley-bottom catchments during wet periods. During transition periods, stream solute export decreased by $34-$ $97 \%$ between the hillslope and valley-bottom catchments for chloride, nitrate, and dissolved organic carbon. In annual terms, stream nitrate export from the valley-bottom catchment $\left(0.32 \pm 0.12 \mathrm{~kg} \mathrm{~N} \mathrm{ha}^{-1} \mathrm{yr}^{-1}\right.$ [average \pm standard deviation]) was $30-50 \%$ lower than from the hillslope catchment $\left(0.56 \pm 0.32 \mathrm{~kg} \mathrm{~N} \mathrm{ha}^{-1} \mathrm{yr}^{-1}\right)$. The annual export of dissolved organic carbon was similar between the two catchments $\left(1.8 \pm 1 \mathrm{~kg} \mathrm{Cha}^{-1} \mathrm{yr}^{-1}\right)$. Our results suggest that hydrological retention in the alluvial zone contributed to reduce stream water and solute export from the valley-bottom catchment during hydrological transition periods when hydrological connectivity between the hillslope and the valley bottom was low.
\end{abstract}

\section{Introduction}

Large riparian forests and well-developed alluvial zones are two of the main contrasting landscape features between hillslope and valley-bottom areas in mountainous regions. The riparian zone is a critical ecotone in the interface between terrestrial and fluvial ecosystems with high potential for biogeochemical processing (Cirmo and McDonnell, 1997; Hedin et al., 1998; Hill, 2000). Riparian vegetation can supply large amounts of fresh particulate organic matter to aquatic ecosystems (Fiebig et al., 1990; Meyer et al., 1998). There is a large flux of dissolved organic carbon (DOC) from riparian soils to stream ecosystems (e.g. Seibert et al., 2009; Hornberger et al., 1994), and this source of organic matter can contribute considerably to the annual export of DOC at the catchment scale (Inamdar and Mitchell, 2006; Pacific et al., 2010). At the same time, riparian zones can act as important sinks of essential nutrients such as nitrate, substantially reducing nitrate export from catchments (Peterjohn and Correll, 1984; Hill, 1996; Vidon et al., 2004a).

A well-developed alluvium can store a large volume of water, integrating the temporal variation of new and old solute inputs. In this sense, the alluvial aquifer acts as a wellmixed groundwater reservoir and can exhibit a chemical signature distinct from hillslope groundwater (Hooper et al., 1998). Moreover, the alluvial zone can strongly affect nearstream subsurface hydrology, and thus the ability of riparian zones to regulate solute fluxes (Pinay et al., 1995; Hill et al., 2004). When the stream and riparian zone are surrounded by an alluvium with a large fraction of coarse material (hereafter, the alluvial riparian zone), high hydraulic conductivity 
can favour the mixing of surface-subsurface water bodies and modify stream flow as well as stream chemistry in many different ways (e.g. Hooper et al., 1998; Hill, 2000; Burns et al., 2001). In temperate streams, where aquifer-to-stream fluxes prevail most of the time, highly conductive alluvial sediments can favour that hillslope groundwater passes through the riparian area, lowering the mean residence time of groundwater in this compartment and thus, diminishing the ability of riparian biota to remove nutrients from groundwater (Vidon et al., 2004b). On the contrary, in arid and semiarid regions where streams usually lose water toward the aquifer (Martí et al., 2000), highly conductive coarse sediments enhance the retention of nutrients from the stream, because the alluvium enlarges water storage zones, increasing hydrological retention and thus, attenuating the advective transport of stream water (e.g. Valett et al., 1996; Morrice et al., 1997; Martí et al., 1997).

Most of the research showing that alluvial riparian zones affect stream hydrology and nutrient cycling is based on reach- and plot-scale experiments, and thus our current understanding of how this ecotone regulates water and nutrient export at the catchment scale is still limited. Recent studies performed in temperate regions have revealed that the capability of the alluvial riparian zone to change water and nutrient export from catchments increases with its size (relative to the hillslope area) and with the turnover time of groundwater in this compartment, which is inversely related to the degree of hydrological connectivity between hillslope and riparian zones (Jencso et al., 2010; Pacific et al., 2010). In semiarid catchments, high water demand by vegetation limits water availability and runoff, so that hydrological connectivity between hillslope and riparian zones tends to be low (Piñol et al., 1991; Meixner et al., 2007). Consequently, the mobilization of water and solutes from the hillslope to the stream is limited to large storm events when hydrological connectivity can eventually increase (Meixner and Fenn, 2004; Meixner et al., 2007). Thus, the potential of the alluvial riparian zone to change stream water and nutrient fluxes should be high in semiarid systems, especially during dry periods, because hydrological connectivity between hillslope and riparian zones is limited, and thus, the turnover time of groundwater in the alluvium may be high.

To explore this idea, we compared monthly discharge as well as stream carbon and nitrogen dynamics between two semiarid nested catchments: one located at the hillslope and the other one located at the valley bottom. In addition to bio-reactive solutes, we analyzed a passive solute (chloride) to discern whether changes in water chemistry between the two catchments reflected solely changes in hydrological processes or integrated differences in biogeochemical processes as well. The valley-bottom stream was surrounded by a welldeveloped alluvium and lost water toward the alluvial riparian zone during hydrological transitions (from dry-to-wet and from wet-to-dry conditions) (Butturini et al., 2003). By contrast, the alluvial riparian zone surrounding the hills- lope stream was minimum, and hillslope groundwater flowed directly into the stream all the year around (Bernal and Sabater, 2008). Previous plot-scale studies performed at the valley bottom have shown contrasting carbon and nitrogen patterns between hydrological transition and wet periods at the alluvial riparian zone (Butturini et al., 2003; Vázquez et al., 2007). The current paper extends this previous work by exploring differences in water and solute fluxes with catchment position between these two contrasting hydrological periods. We expect that differences in water and solute dynamics between the hillslope and valley-bottom streams will be accentuated during hydrological transitions when hydrological disconnection between the two catchments is high. In particular, we expect a decrease in stream water and solute fluxes between the hillslope and valley-bottom catchments during hydrological transitions because streamto-aquifer water fluxes may favour hydrological retention at the valley bottom.

\section{Study site}

\subsection{Climate}

The Fuirosos Stream Watershed (FSW) is located in the Natural Park of Montnegre-Corredor $60 \mathrm{~km}$ from Barcelona, in northeastern Spain (latitude $41^{\circ} 42^{\prime} \mathrm{N}$, longitude $2^{\circ} 34^{\prime}$, altitude range $50-770 \mathrm{~m}$ a.s.1.). The climate is typically Mediterranean, with temperatures ranging from a monthly mean of $3^{\circ} \mathrm{C}$ in January to $24^{\circ} \mathrm{C}$ in August. Average annual precipitation is $750 \mathrm{~mm} \mathrm{yr}^{-1}$, and the climate is Mediterranean subhumid (sensu Strahler and Strahler, 1989). The distribution of rainfall throughout the year is irregular, and it rarely snows.

\subsection{The catchment}

The FSW has a drainage area of $16 \mathrm{~km}^{2}$ and is mainly underlain by granite with minor areas of sericitic schists. Leucogranite is the dominant rock type ( $48 \%$ of the area), followed by biotitic granodiorite (27\% of the area) (IGME, 1983). There is an identifiable alluvial zone at the valley bottom that resulted from the transport and deposition of coarse material from the catchment (mainly sands and gravels). The alluvial zone is $50-130 \mathrm{~m}$ wide, and it surrounds the stream and the riparian zone for almost $4 \mathrm{~km}$ along the stream (Fig. 1).

The soils at the FSW are poorly developed, with a very thin organic $\mathrm{O}$ horizon, or more frequently an Ao horizon, which becomes rapidly (in less than 5-cm depth) a B horizon (Bech and Garrigó, 1996). Soils at the FSW (from the top to the valley bottom) are usually classified as Entisols (great group Xerorthents), Alfisols (great group Haploxeralfs), and less frequently as Inceptisols (great group Xerochrepts) (USDA 1975-1992) (Bech and Garrigó, 1996). The riparian soils are sandy soils, Typic Xerochrepts (60\% sand, $34 \%$ silt and $5.3 \%$ clay) with low organic matter content $(3-6 \%$ in the 


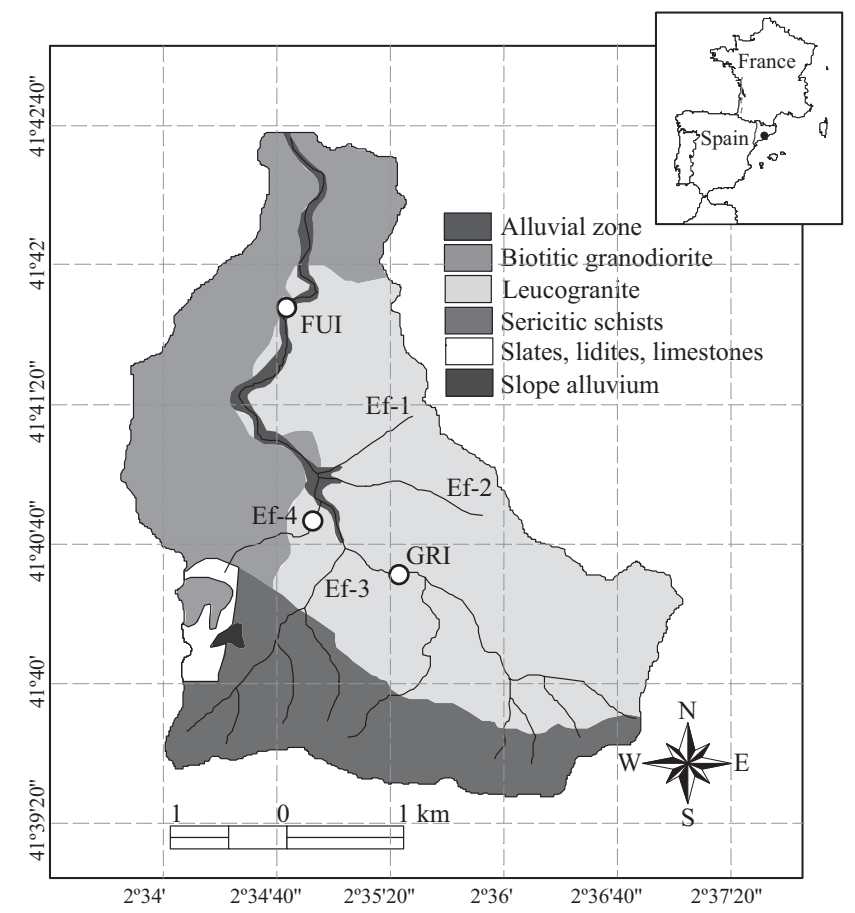

Fig. 1. Lithological units in the Fuirosos Stream Watershed (Montnegre-Corredor Natural Park, NE Spain) (sensu IGME, 1983). There is an identifiable alluvial zone at the valley bottom. Circles indicate the sampling stations located at the valley-bottom catchment (FUI, $10.5 \mathrm{~km}^{2}$ ) and at the hillslope catchments Grimola $\left(\mathrm{GRI}, 3.5 \mathrm{~km}^{2}\right)$ and Ef-4 $\left(0.3 \mathrm{~km}^{2}\right)$.

first $10 \mathrm{~cm}$ ) (Bernal et al., 2003). The catchment is mainly covered by perennial cork oak (Quercus suber), evergreen oak (Quercus ilex ssp. ilex) and pine trees (Pinus pinea, $P i$ nus pinaster and Pinus halepensis). In the valley head there is mixed deciduous woodland of chestnut (Castanea sativa), hazel (Corylus avellana), and oak (Quercus pubescens). The riparian forest is conformed by alder (Alnus glutinosa) and plane (Platanus acerifolia). Agricultural fields occupy less than $2 \%$ of the catchment area, and most of them are semiabandoned.

For the present study, we monitored intensively two third-order streams draining nested catchments: Fuirosos $\left(10.5 \mathrm{~km}^{2}\right)$ that was surrounded by a well-developed alluvium and a large riparian forest, and Grimola $\left(3.5 \mathrm{~km}^{2}\right)$ with a minimum alluvial riparian zone. The Grimola sampling station was located $1.5 \mathrm{~km}$ upstream of the alluvial riparian zone, while the Fuirosos sampling station was located $3 \mathrm{~km}$ after the beginning of the alluvial riparian zone (Fig. 1). The alluvial zone occupied $2.1 \%$ of the Fuirosos catchment area and surrounded a large riparian forest (10-20 m width) and the stream channel ( $3-5 \mathrm{~m}$ width). The Grimola streambed was mainly formed by bedrock, and hillslope groundwater flowed directly into the stream channel. The Fuirosos stream had four main effluents (Ef-1, Ef-2, Ef-3, and Ef-4). The Ef-1 and Ef-2 effluents ran dry during the period of study. The Ef-
3 and Ef- 4 catchments had similar lithology and vegetation to the Grimola catchment, and they were outside the influence of the alluvial zone (Fig. 1).

Stream flow at the Fuirosos stream and all its effluents was intermittent. The cessation of flow occurred in summer, and it lasted for several weeks or even months depending on the dryness of the year. During the two studied water years, the duration of the summer drought was similar (11 and 14 weeks, respectively). The water year started in September when the stream flow recovered from autumn storm events. During the hydrological transition from dry-to-wet conditions, stream water at the Fuirosos site infiltrated into the alluvial riparian zone (Butturini et al., 2003). This valleybottom stream lost water toward the aquifer until November, and after that, aquifer-to-stream groundwater fluxes predominated until early summer (Butturini et al., 2003). Stream water losses have been detected during the transition from wetto-dry conditions in late summer (Bernal and Sabater, 2008). At the Grimola stream, aquifer-to-stream fluxes prevailed and there was no evidence of stream water loss (Bernal and Sabater, 2008).

\section{Material and methods}

\subsection{Field measurements and chemical water analysis}

Air temperature and precipitation (collected with a tipping bucket rain gage) data were recorded at $15 \mathrm{~min}$ intervals at the meteorological station commissioned in April 1999 at the FSW. Stream water level at Fuirosos was monitored at 30 min intervals from September 1998 until May 2002 using a water pressure sensor connected to an automatic stream water sampler $\left(\mathrm{Sigma}^{\odot} 900 \mathrm{Max}\right)$. From September 2000, similar equipment was used to monitor stream water level at Grimola (Fig. 2). An empirical relationship between discharge and stream water level was obtained at each site using the "slug" chloride addition method in the field (Gordon et al., 1992). Slug additions were performed under a wide range of hydrological conditions at both streams: Fuirosos $\left(n=36\right.$, from 0.8 to $\left.14251 \mathrm{~s}^{-1}\right)$ and Grimola $(n=27$, from 0.8 to $4801 \mathrm{~s}^{-1}$ ). Stream discharge ranged between the values covered by these additions during $>99 \%$ of the time at both sites.

Stream water samples were taken manually at least once every ten days (except during cessation of flow in summer) from September 2000 to March 2002 at the Fuirosos, Grimola and Ef-4 streams. Field campaigns started at $\sim$ 09:00 a.m. (solar time), and stream water samples were collected from the different sampling sites within 2 to $5 \mathrm{~h}$. The automatic samplers at the Fuirosos and Grimola sites were programmed to start collecting water samples at an increment in stream water level of $2-3 \mathrm{~cm}$ and $0.5-1 \mathrm{~cm}$, respectively. This increase in water level equalled a 2 to $101 \mathrm{~s}^{-1}$ increase in stream discharge depending on the previous base 
a

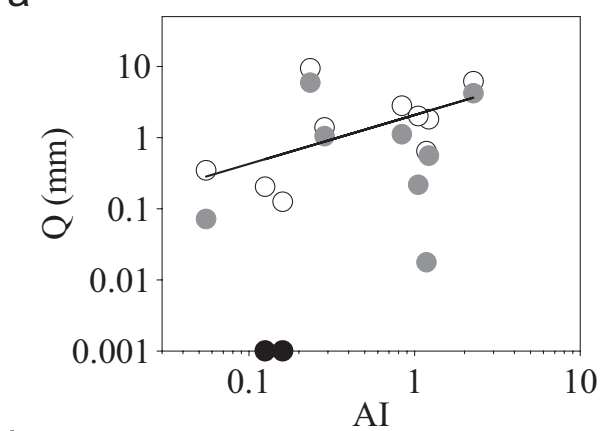

b

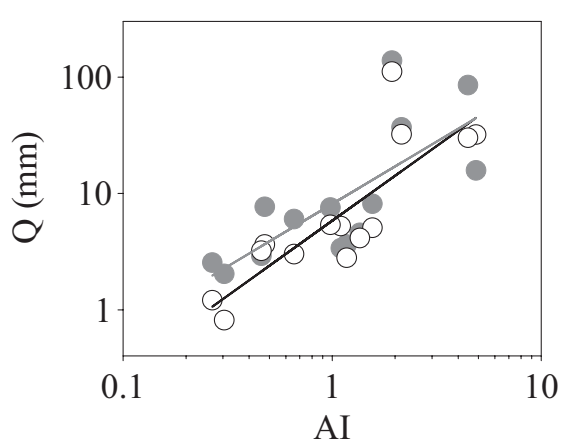

Fig. 2. Relationship between monthly aridity index (AI) and stream runoff $(Q)$ at the valley-bottom (grey circles) and hillslope (white circles) catchments during (a) the transition and (b) wet periods. The grey and black lines indicate the power fit between $\mathrm{AI}$ and $Q$ for the valley-bottom and hillslope catchments, respectively (only when significant, $p<0.01$ ). The black circles correspond to months when the valley-bottom stream ran dry.

flow conditions. To capture changes in stream chemistry during the rising limb of the storm hydrograph, the automatic samplers were programmed to collect water samples at intervals of 30-60 min during the first 2-4 h; subsequent samples were collected at intervals of $4-6 \mathrm{~h}$.

We installed an automatic sampler (without water pressure sensor) at the Ef-4 stream. In this case, water samples were collected at regular time intervals either hourly (if storms expected) or daily (if no storms expected). To assess whether the Ef-4 stream water samples were collected during base flow or storm flow conditions, we installed a water pressure sensor connected to a data logger (Campbell $\left.{ }^{\odot} \mathrm{CR} 10 \mathrm{X}\right)$ next to the automatic water sampler. Although the Ef-4 stream was not sampled as intensively as the other two streams, these data were useful for characterizing the stream water chemistry of the hillslope effluents.

All water samples were filtered through pre-ashed GF/F glass fibre filters and stored at $4{ }^{\circ} \mathrm{C}$ until analysed (usually in $<7$ days). Chloride $\left(\mathrm{Cl}^{-}\right)$was analyzed by capillary electrophoresis (Waters, CIA-Quanta 5000) (Romano and Krol, 1993). Dissolved nitrogen was measured colorimetrically with a Technicon-Autoanalyser (Technicon, 1976). Nitrate $\left(\mathrm{NO}_{3}^{-}\right)$was measured by the Griess-Ilosvay method (Keeney and Nelson, 1982) after reduction by percolation through a copperized cadmium column; ammonium $\left(\mathrm{NH}_{4}^{+}\right)$was measured after oxidation with salicilate using sodium nitroprusside as a catalyst (Hach, 1992). Total dissolved nitrogen (TDN) was analyzed from March 2000 to March 2002. For measuring TDN, the sample was previously digested with UV light and potassium persulfate (Valderrama, 1981; Walsh, 1989) and then analyzed for $\mathrm{NO}_{3}^{-}-\mathrm{DON}$ concentration was calculated by subtracting $\mathrm{NO}_{3}^{-}$and $\mathrm{NH}_{4}^{+}$from TDN. DOC samples were analyzed using a high-temperature catalytic oxidation (Shimadzu TOC analyzer).

\subsection{Data analysis}

Hydrological stream-aquifer interactions at the Fuirosos stream have been intensively analyzed (Butturini et al., 2002, 2003; Bernal and Sabater, 2008). These previous studies showed that stream-to-aquifer water fluxes occur in the FSW valley bottom during hydrological transition periods (from dry-to-wet and from wet-to-dry conditions) due to highly conductive alluvial sediments. Based on this previous knowledge, we considered two hydrological periods: the transition period (from June to October) when there is a high likelihood that stream-to-aquifer water fluxes occur, and the wet period (from November to May) when the aquifer-to-stream water fluxes prevail. Accordingly, all the environmental variables included in this study, as well as stream water and solute fluxes from the hillslope and valley-bottom catchments, were calculated separately for each hydrological period.

\subsubsection{Environmental variables}

From the meteorological data set, we calculated monthly precipitation (in mm month ${ }^{-1}$ ) and average monthly air temperature (in ${ }^{\circ} \mathrm{C}$ ). We calculated daily potential evapotranspiration (PET, in $\mathrm{mm} \mathrm{day}^{-1}$ ) with the Penman-Monteith method (Campbell and Norman, 1998). To characterize the environmental conditions for each water year and for each hydrological period, we calculated the UNEP Aridity In$\operatorname{dex}(\mathrm{AI})$, which is $\mathrm{P} / \mathrm{PET}$. Values of $\mathrm{AI} \geq 1,0.65<\mathrm{AI}<1$, $0.5<\mathrm{AI}<0.65,0.2<\mathrm{AI}<0.5,0.05<\mathrm{AI}<0.2, \mathrm{AI} \leq 0.05$ indicate humid, dry land, dry sub-humid, semi-arid, arid and hyper-arid conditions, respectively (UNEP, 1992).

\subsubsection{Stream water export}

We estimated monthly stream water export $(Q$, in mm month ${ }^{-1}$ ) from the Grimola and Fuirosos catchments by linearly interpolating instantaneous discharge between consecutive dates and summing up values for each month. To investigate changes in stream discharge between the hillslope and valley-bottom catchments, we calculated the relative difference in $Q(\Delta Q$, in $\%)$ between the two sites with $100 *\left(Q_{\text {fui }}-Q_{\text {gri }}\right) / Q_{\text {gri }}$, for each hydrological period. Values of $\Delta Q \approx 0 \%$ indicated similar stream water export from the two catchments. Negative $\Delta Q$ values indicated that stream water export from the valley-bottom catchment was 
lower than from the hillslope catchment; positive $\Delta Q$ values indicated the opposite.

\subsubsection{Stream solute concentrations and fluxes}

We calculated monthly volume-weighted solute concentrations (in $\mathrm{mg}^{-1}$ ) for each of the two catchments. For each solute $i$, we calculated monthly stream solute export $\left(E_{i}\right.$, in $\mathrm{g} \mathrm{ha}^{-1}$ ) from the hillslope and valley-bottom catchments by multiplying instantaneous concentration by daily discharge. Daily volume-weighted concentration was used when more than one stream water sample per day was available. Daily solute concentrations were estimated by linear interpolation of measured solute concentrations (Hinton et al., 1997). We calculated the relative difference in stream solute export between the two catchments $\left(\Delta E_{i}\right.$, in $\left.\%\right)$ with $100 *\left(E_{\text {fui }, i}-\right.$ $\left.E_{\mathrm{gri}, i}\right) / E_{\mathrm{gri}, i}$ for each hydrological period.

To explore differences in stream water chemistry between hillslope streams, we compared instantaneous solute concentration for stream water samples collected within the same day from the Grimola and Ef-4 streams.

\subsubsection{Statistical analysis}

We used a Wilcoxon/Kruskal-Wallis test to examine whether significant differences existed in stream solute concentration between (i) the transition and wet periods for each catchment, and (ii) the hillslope and valley-bottom catchments for a given hydrological period. We performed correlation analysis between different environmental variables using a Spearman rank correlation coefficient $(\rho)$.

We used a Wilcoxon signed-rank test to examine whether solute concentration in water samples collected from different streams within the same day differed significantly between each other. Non-parametric tests were chosen, because concentrations showed a skewed distribution (Helsel and Hirsch, 1992). In all cases differences were considered significant when $p<0.01$.

\section{Results}

\subsection{Environmental variables}

Annual $P$ was 711 and $804 \mathrm{~mm} \mathrm{yr}^{-1}$ during 2000-2001 and 2001-2002, respectively. Annual PET was similar for the two water years (1050 $\mathrm{mm} \mathrm{yr}^{-1}$ for 2000-2001 and $931 \mathrm{~mm} \mathrm{yr}^{-1}$ for 2001-2002). Annual AI ranged between 0.67 and 0.86. When analyzing each hydrological period separately, we found that the AI was particularly low during the transition period and it exhibited typical values of semiarid conditions (Table 1). In contrast, during the wet period $P$ and PET were similar and values of AI were $\geq 1$.
Table 1. Cumulative precipitation $(P)$ and potential evapotranspiration (PET), aridity index (AI), and average air temperature $(T)$ for the transition and wet periods during the study period at the Fuirosos Stream Watershed. The range of monthly temperature for each period is shown in parenthesis.

\begin{tabular}{lcccc}
\hline & $P(\mathrm{~mm})$ & PET $(\mathrm{mm})$ & AI & $T\left({ }^{\circ} \mathrm{C}\right)$ \\
\hline \multicolumn{5}{c}{ WY 2000-2001 } \\
\hline Transition & 263 & 614 & 0.43 & $19.6(13.9,23.5)$ \\
Wet & 448 & 436 & 1.03 & $10.8(7.5,17.1)$ \\
\hline \multicolumn{5}{c}{ WY 2001-2002 } \\
\hline Transition & 256 & 566 & 0.45 & $20.4(17.3,22.8)$ \\
Wet & 548 & 365 & 1.5 & $9.8(5.28,15.6)$ \\
\hline
\end{tabular}

\subsection{Stream water export}

During the transition period, stream runoff decreased between the hillslope and valley-bottom catchments ( $\Delta Q<0 \%$ ), while the opposite trend was observed during the wet period (Table 2). Differences in monthly $Q$ between the hillslope and valley-bottom catchments were particularly large during the transition period (Fig. 2).

There was a significant and positive correlation between monthly AI and $Q$ for both the hillslope $(\rho=0.7)$ and valleybottom $(\rho=0.63)$ catchments $(n=24, p<0.001$ for both catchments). During the transition period, $Q$ at the valley bottom tended to be lower than at the hillslope for a given AI value (Fig. 2a). By contrast, the hillslope and valley-bottom catchments showed a similar $\mathrm{AI}-Q$ relationship during the wet period (Fig. 2b).

\subsection{Stream solute concentrations}

At the valley bottom, stream $\mathrm{Cl}^{-}$concentration was higher during the transition period $\left(24.9 \pm 5.3 \mathrm{mg}^{-1}\right)$ than during the wet period $\left(19.9 \pm 4.5 \mathrm{mgl}^{-1}\right)$, although the difference between the two periods was only marginally significant (Wilcoxon/Kruskal-Wallis test, $p=0.06$ ). There were no significant differences in monthly volume-weighted $\mathrm{Cl}^{-}$concentration between the hillslope and valley-bottom streams (Wilcoxon/Kruskal-Wallis test, $p>0.05$ ) (Fig. 3a).

At the valley bottom, monthly volume-weighted $\mathrm{NO}_{3}^{-}$concentration followed a seasonal pattern with maximum in winter and minimum in summer (Fig. 3b). The hillslope stream did not exhibit such a marked seasonality, because $\mathrm{NO}_{3}^{-}$concentration was high in winter as well as in the transition period (Fig. 3b).

There were no significant differences in stream DON concentration between the two catchments (Wilcoxon/KruskalWallis test, $p>0.05$ ). Both streams showed no significant differences in stream DON concentration between the transition and wet periods (Wilcoxon/Kruskal-Wallis test, $p>$ $0.05)$. Monthly volume-weighted DON concentration ranged 
Table 2. Cumulative water $(Q)$ and solute export $\left(E_{i}\right)$ from the hillslope (gri) and valley-bottom (fui) catchments during the transition and wet periods for the study period. The relative difference in stream water $(\Delta Q)$ and solute $\left(\Delta E_{i}\right)$ export between the two catchments is shown in each case.

\begin{tabular}{|c|c|c|c|c|c|c|c|c|c|c|c|c|c|c|c|}
\hline & \multicolumn{3}{|c|}{$Q$} & \multicolumn{3}{|c|}{$\mathrm{Cl}^{-}$} & \multicolumn{3}{|c|}{$\mathrm{NO}_{3}^{-}$} & \multicolumn{3}{|c|}{ DON } & \multicolumn{3}{|c|}{ DOC } \\
\hline & $\begin{array}{l}Q_{\text {gri }} \\
\mathrm{mm}\end{array}$ & $\begin{array}{l}Q_{\text {fui }} \\
\mathrm{mm}\end{array}$ & $\begin{array}{c}\Delta Q \\
\%\end{array}$ & $\begin{array}{c}\begin{array}{c}E_{\text {gri }} \\
\mathrm{gha}^{-1}\end{array}\end{array}$ & $\begin{array}{c}E_{\text {gri }} \\
\text { gha }^{-1}\end{array}$ & $\begin{array}{c}\Delta E \\
\%\end{array}$ & $\begin{array}{c}E_{\text {gri }} \\
\text { gha }^{-1}\end{array}$ & $\begin{array}{c}\begin{array}{c}E_{\text {gri }} \\
\mathrm{gha}^{-1}\end{array}\end{array}$ & $\begin{array}{c}\Delta E \\
\%\end{array}$ & $\begin{array}{c}E_{\text {gri }} \\
\text { gha }^{-1}\end{array}$ & $\begin{array}{c}E_{\text {gri }} \\
\mathrm{gha}^{-1}\end{array}$ & $\begin{array}{c}\Delta E \\
\%\end{array}$ & $\begin{array}{c}E_{\text {gri }} \\
\text { gha }^{-1}\end{array}$ & $\begin{array}{c}E_{\text {gri }} \\
\mathrm{gha}^{-1}\end{array}$ & $\begin{array}{c}\Delta E \\
\%\end{array}$ \\
\hline Transition & 9 & 5 & -44 & 2154 & 1416 & -34 & 93 & 19 & -80 & 35 & 36 & 3 & 521 & 288 & -45 \\
\hline Wet & 76 & 127 & 68 & 12375 & 20881 & 69 & 698 & 385 & -45 & 350 & 226 & -35 & 2179 & 2454 & 13 \\
\hline Total & 84 & 132 & 57 & 14529 & 22298 & 53 & 791 & 404 & -49 & 385 & 262 & -32 & 2700 & 2742 & 2 \\
\hline Transition & 16 & 8 & -48 & $1061^{\mathrm{a}}$ & $303^{a}$ & -71 & $26^{\mathrm{a}}$ & $0.8^{\mathrm{a}}$ & -97 & $10^{\mathrm{a}}$ & $27^{\mathrm{a}}$ & 176 & $159^{\mathrm{a}}$ & $57^{\mathrm{a}}$ & -64 \\
\hline Wet & 164 & 197 & 20 & $4683^{b}$ & $5129^{b}$ & 10 & $313^{\mathrm{b}}$ & $245^{\mathrm{b}}$ & -22 & $71^{\mathrm{b}}$ & $91^{\mathrm{b}}$ & 29 & $751^{\mathrm{b}}$ & $865^{\mathrm{b}}$ & 15 \\
\hline Total & 180 & 206 & 14 & 5744 & 5432 & -5 & 339 & 246 & -27 & 81 & 118 & 46 & 910 & 922 & 1 \\
\hline
\end{tabular}

${ }^{\mathrm{a}}$ Only September and October, ${ }^{\mathrm{b}}$ from November to March.

from 0.04 to $1.8 \mathrm{mg} \mathrm{N1}^{-1}$ and did not show any seasonal pattern (Fig. 3c).

Monthly volume-weighted DOC concentration peaked in September at both the hillslope and valley-bottom streams (Fig. 3d). Both streams showed no significant differences in stream DOC concentration between the transition and wet periods (Wilcoxon/Kruskal-Wallis test, $p>0.05$, for both streams).

There were no significant differences in stream $\mathrm{Cl}^{-}$, DOC, and DON concentration between the Ef-4 and Grimola streams (Fig. 4). Only stream $\mathrm{NO}_{3}^{-}$concentration was higher at Grimola than at Ef-4 during the wet period (Fig. 4b). During the transition period, instantaneous $\mathrm{NO}_{3}^{-}$ concentration was higher at the hillslope streams than at the valley-bottom stream (Fig. 4b). In contrast, instantaneous DOC concentration was higher at the valley-bottom stream than at the hillslope streams, especially during the transition period (Fig. 4d).

\subsection{Catchment solute export}

Relative changes in stream $\mathrm{Cl}^{-}$export between the hillslope and valley-bottom catchments $\left(\Delta E_{\mathrm{Cl}}\right)$ were in agreement with those observed for stream discharge during both the transition and wet periods (Table 2). During the transition period, not only $\Delta E_{\mathrm{Cl}}$ values, but also $\Delta E_{\mathrm{DOC}}$ and $\Delta E_{\mathrm{NO}_{3}}$ values, were $<0 \%$ (Table 2). Moreover, values of $\Delta E_{\mathrm{NO}_{3}}$ were $<0 \%$ during the wet period, and in annual terms the stream export of $\mathrm{NO}_{3}^{-}$was $\sim 30-50 \%$ lower from the valley-bottom catchment than from the hillslope catchment (Table 2). In contrast, the annual export of DOC was similar between the two catchments $(<3 \%$ of difference, Table 2). Values of $\Delta E_{\mathrm{DON}}$ did not show a consistent pattern between the two studied water years (Table 2).

\section{Discussion}

There is an increasing body of knowledge showing that major hydrological and biogeochemical processes change as streams flow from the hillslope to the valley bottom (Covino and McGlynn, 2007; Jencso et al., 2010). Most of this research is based on studies performed in temperate regions where hillslope-riparian hydrological connectivity is high, especially during snowmelt (Jencso et al., 2009, 2010). In the current study, we shed some light on the effect of catchment position on hydrological and biogeochemical processes at the catchment-scale in semiarid regions by comparing two nested catchments with no snowpack that suffered water limitation during long periods. We found substantial differences in water, $\mathrm{C}$ and $\mathrm{N}$ fluxes between the hillslope and valleybottom streams during hydrological transitions when semiarid conditions prevailed. Based on the results presented here and on previous plot-scale studies performed at the FSW, we discuss the potential effect of the alluvial riparian zone on stream hydrology and water chemistry in these semiarid catchments.

\subsection{Influence of the alluvial riparian zone on stream water export}

We found a positive relationship between $Q$ and AI for both catchments, an indication that water availability in the FSW drove stream water export, as expected for semiarid catchments such as ours (Piñol et al., 1991). Differences in stream water export between the two catchments were small during the wet period, whereas each catchment showed a distinct pattern between $Q$ and AI during the transition period. In addition, stream water export consistently decreased (by $>40 \%$ ) between the hillslope and valley-bottom catchments during the transition period. These results agree with previous studies showing that the valley-bottom stream lost water toward the aquifer during hydrological transitions, while 
a

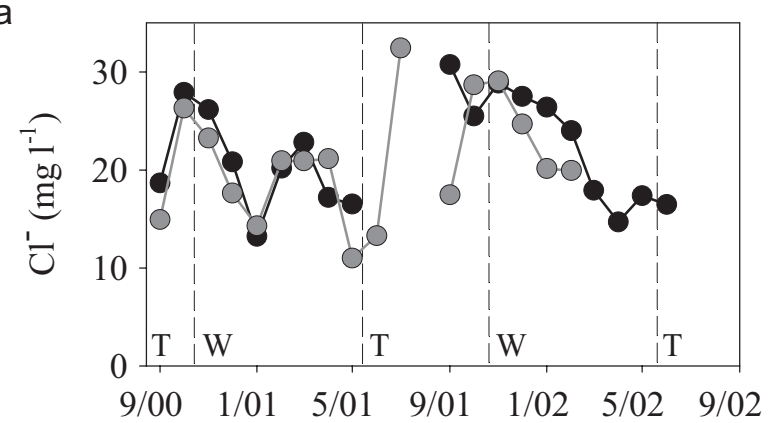

b

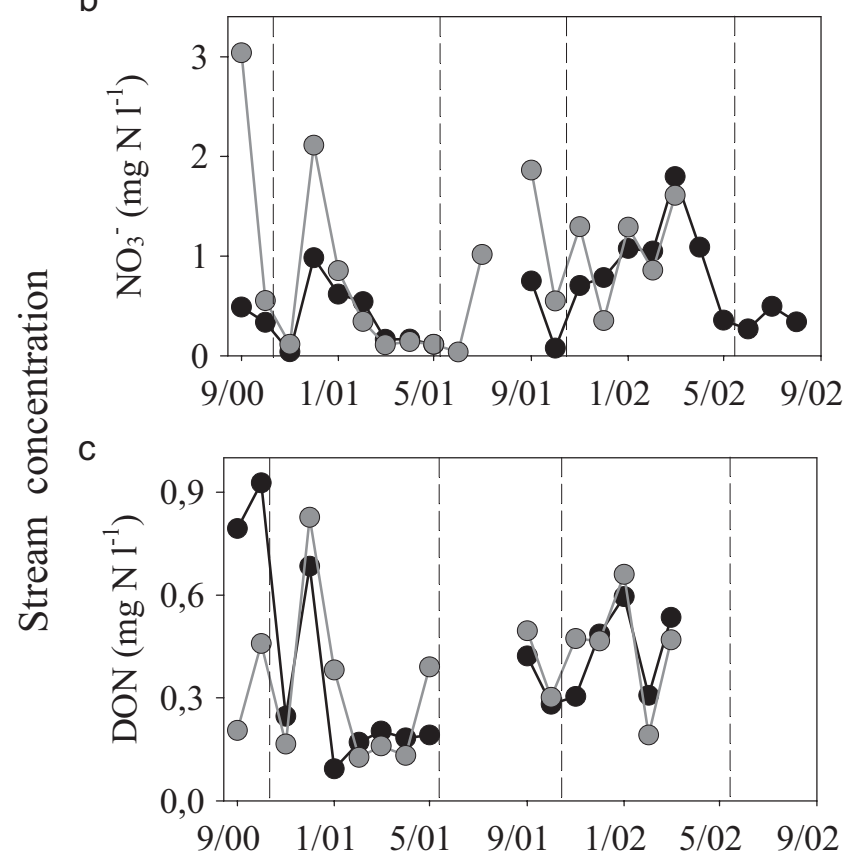

d

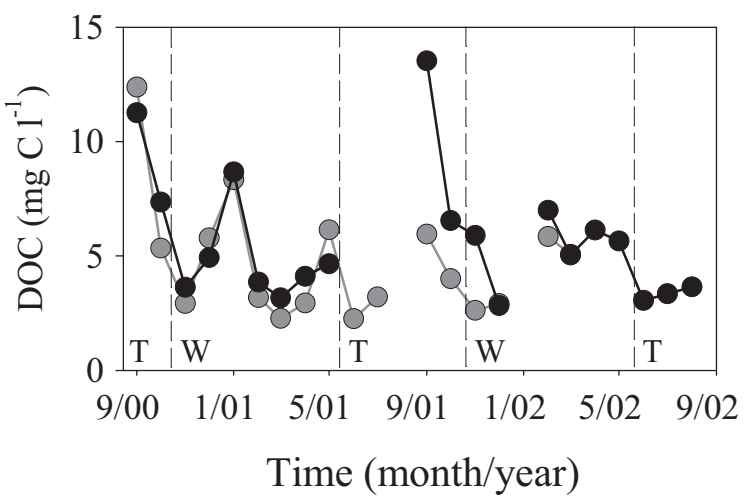

Fig. 3. Monthly volume-weighted solute concentration for (a) $\mathrm{Cl}^{-}$, (b) $\mathrm{NO}_{3}^{-}$, (c) DON, and (d) DOC at the hillslope (grey) and the valley-bottom (black) streams during the study period. T: transition period; W: wet period. there were no stream-to-aquifer fluxes at the hillslope stream (Butturini et al., 2003; Vázquez et al., 2007; Bernal and Sabater, 2008).

Stream-to-aquifer fluxes at the valley bottom were attributed to differences in the hydraulic head between the aquifer and stream surface water, a process favoured by the high hydraulic conductivity of the alluvial sediments (5$20 \mathrm{~m} \mathrm{day}^{-1}$; Butturini et al., 2003). Similar results have been reported for other alluvial streams in semiarid regions worldwide (Triska et al., 1993; Morrice et al., 1997). This difference in stream-aquifer hydrological interactions between the two sites could explain why stream discharge was several times lower at the valley bottom than at the hillslope during transition periods.

Another feasible mechanism that could exacerbate the difference between aquifer and stream water hydraulic heads at the FSW valley bottom is a disproportionately lower contribution of hillslope groundwater to stream discharge downstream of the Grimola sampling station. Even temperate catchments such as those at the Hubbard Brook Experimental Forest (NH, USA) experience severe hydrological disconnection between hillslope and riparian zones during dry periods (Detty and McGuire, 2010). Moreover, the transition between low and high hydrological connectivity is a complex and nonlinear process (McGuire and McDonnell, 2010), which could explain the large differences in $Q$ observed between the hillslope and valley-bottom catchments during the transition period. Our findings suggest that hydrological processes and stream runoff generation at the FSW were linked to climatic conditions and that aridness can accentuate differences in stream water export between hillslope and valley-bottom catchments.

\subsection{Hydrological and biogeochemical solute retention in the alluvial riparian zone}

In concordance with the expectation that stream-to-aquifer water flux would increase the hydrological retention of solutes at the alluvial riparian zone during hydrological transitions, the drop in stream water export between the hillslope and the valley bottom was accompanied by a drop in stream solute export $\left(\mathrm{Cl}^{-}, \mathrm{NO}_{3}^{-}\right.$, and DOC). Other studies in semiarid regions have reported increased water residence time in alluvial zones when sediments have high hydraulic conductivity, which has important implications for nutrient cycling and retention (e.g. Valett et al., 1996, 1997; Morrice et al., 1997; Martí et al., 1997).

If increased hydrological retention had been the only mechanism responsible for decreased stream nutrient fluxes at the valley bottom, we might expect no changes in nutrient concentration between the hillslope and valley-bottom streams. However, stream $\mathrm{NO}_{3}^{-}$concentration dropped significantly between the hillslope and the valley bottom during transition periods. Such decrease in $\mathrm{NO}_{3}^{-}$could respond to increased immobilization of inorganic $\mathrm{N}$ by microorganisms 

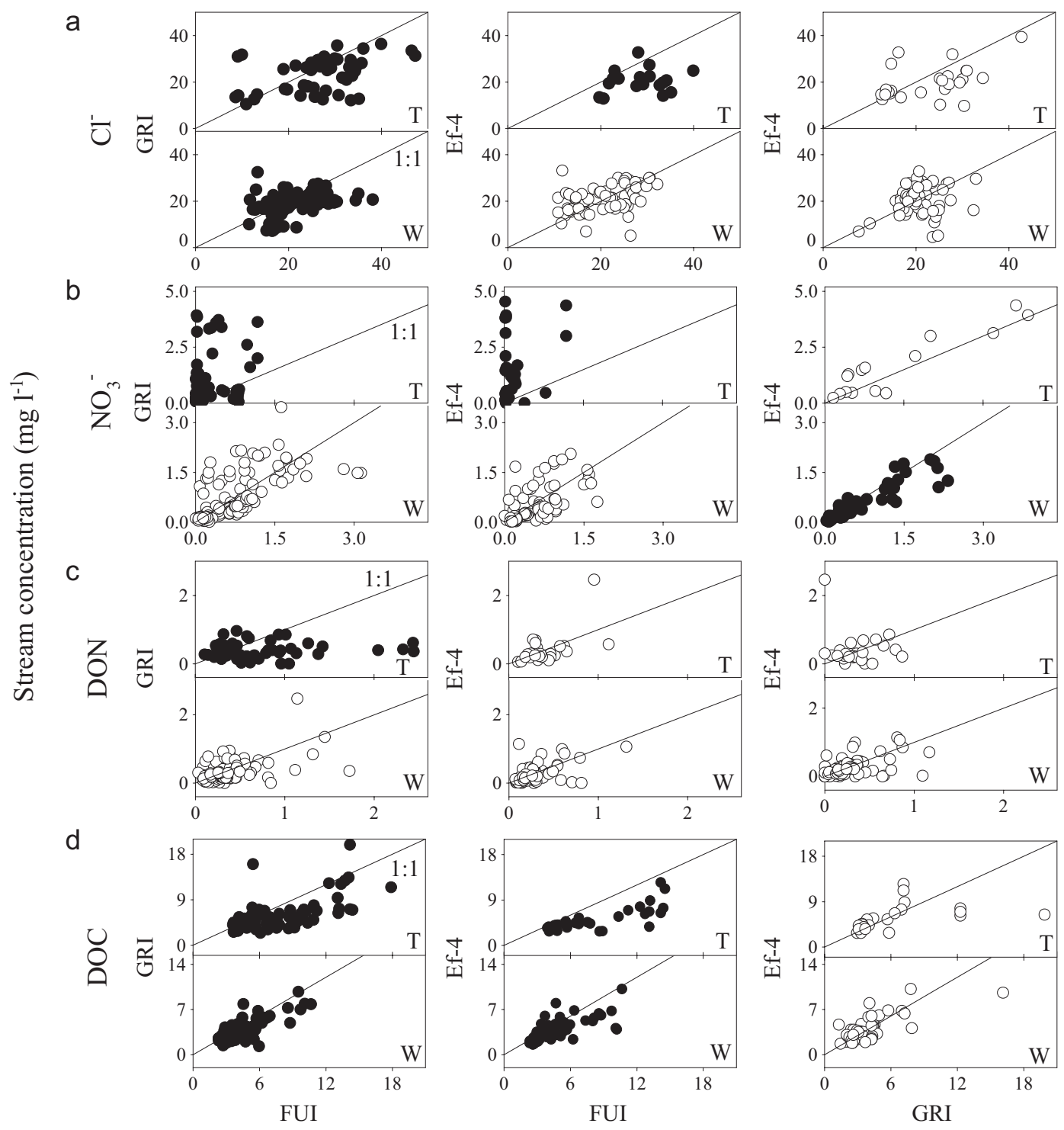

Stream concentration $\left(\mathrm{mg}^{-1}\right)$

Fig. 4. Dispersion plots between instantaneous solute concentration for valley-bottom (FUI) and hillslope (GRI and Ef-4) stream water samples collected within the same day: (a) $\mathrm{Cl}^{-}$, (b) $\mathrm{NO}_{3}^{-}$, (c) DON, and (d) DOC. T: transition period; W: wet period. The 1:1 line is shown in black. Circles are black only when differences between solute concentrations were statistically significant $(p<0.01)$.

colonizing fresh leaf litter stored in the streambed during summer and autumn (Mulholland et al., 1992). The riparian forest at the valley bottom supplies about 0.15$0.49 \mathrm{~kg} \mathrm{C} \mathrm{m}^{-2} \mathrm{yr}^{-1}$ to the adjacent stream mainly as leaf litter (Bernal et al., 2003; Acuña et al., 2007). Such a large supply of organic substrate enhances extremely high peaks of heterotrophic activity in autumn (Acuña et al., 2004), which could promote the immobilization of inorganic $\mathrm{N}$ by the microbial stream community.

Nitrate uptake by riparian vegetation and/or microbial denitrification in riparian soils could also contribute to decrease $\mathrm{NO}_{3}^{-}$concentration in the valley-bottom stream (Peterjohn and Correll, 1984; Vidon et al., 2004a). However, Butturini et al. (2003) reported a marked increase, rather than a decrease, in $\mathrm{NO}_{3}^{-}$concentration at the FSW riparian groundwater during hydrological transitions due to the dissolution of salt buildup in the riparian soil during the dry period. This phenomenon has also been documented in other arid and semiarid regions (Heffernan and Sponseller, 2004; Meixner et al., 2007). That we observed consistently lower $\mathrm{NO}_{3}^{-}$ concentration in the valley-bottom stream than in the two hillslope streams suggests that the stream-to-aquifer water flux enhanced the retention of $\mathrm{NO}_{3}^{-}$released by the riparian 
soil during the transition period, which otherwise would be flushed to the stream.

In annual terms, $\mathrm{NO}_{3}^{-}$export from the valley-bottom catchment was 30-50\% lower than from the hillslope catchment. A dilution effect due to some other water sources seems unlikely since the drop in $\mathrm{NO}_{3}^{-}$was not accompanied by a decrease in $\mathrm{Cl}^{-}$flux. Retention of $\mathrm{NO}_{3}^{-}$in the alluvial riparian zone during the wet period could partially explain the decrease of stream $\mathrm{NO}_{3}^{-}$flux from the hillslope to the valley bottom (Butturini et al., 2003). Although previous studies indicated that soil denitrification is small in this semiarid catchment (Bernal et al., 2003), other hot spots and/or hot moments of $\mathrm{NO}_{3}^{-}$removal can not be ruled out.

\subsection{Riparian vegetation as a source of dissolved organic matter to stream ecosystems}

Riparian forests typically composed of deciduous species provide fresh leaf litter to the stream and forest floor so that riparian soils are often considered an important source of particulate and dissolved organic matter to streams (Fiebig et al., 1990; Hinton et al., 1997; Acuña et al., 2004). For instance, the hydrologic flushing of DOC from shallow organic riparian soil layers has been well documented in temperate (e.g. Hornberger et al., 1994) as well as in semiarid regions (e.g. Valett et al., 2005). Therefore, one would expect an increase in dissolved organic matter (DOM) between the hillslope and valley-bottom streams because of the local supply of DOM by the riparian forest at the valley bottom. Supporting this idea, instantaneous DOC concentration was higher at the valley-bottom stream than at the hillslope streams (Grimola and Ef-4) during both the transition and wet periods. Similarly, other studies have reported higher stream DOC concentration for catchments with wetlands and riparian zones than for catchments without them (Hinton et al., 1998; Inamdar and Mitchell, 2006; Creed et al., 2008). Other parts of the catchment could act as DOC sources to the valley-bottom stream; yet, the fact that the two hillslope streams had similar DOC concentration suggests a consistent source of DOC through the FSW hillslopes.

In contrast to the idea that the FSW riparian forest acts as an extra source of DOM to the stream, stream DOC export decreased by $45-64 \%$ between the hillslope and the valley bottom during the transition period, despite the large amount of riparian leaf litter stored at the valley-bottom streambed during summer drought (Acuña et al., 2004). This finding is not surprising when taking into account that the valleybottom stream lost water toward the aquifer during transition periods, reducing stream water export as well as stream nutrient flux.

During the wet period, we did measure $\Delta E_{\mathrm{DOC}}>\Delta Q$ as well as a $\sim 15 \%$ increase in the flux of stream DOC between the hillslope and valley-bottom catchments, pointing toward an extra source of DOC at the valley bottom. Yet, the difference in the annual hydrological export of DOC between the two catchments was small $(<2 \%)$, evidencing the limited capacity of this riparian forest to supply DOC to the stream. Recently, Pacific et al. (2010) concluded that riparian systems have an impact on annual stream DOC export only when there is a significant riparian-to-hillslope area ratio (at least $5 \%$ ). Concordantly, our results indicated that the FSW riparian forest ( $2 \%$ of the catchment area) was too small to modify annual stream DOC export in this semiarid catchment.

In contrast to DOC, the flux of DON increased between the hillslope and valley-bottom streams during transition periods, although the magnitude of change was extremely different between the two water years (3\% vs. $170 \%)$. The $\Delta E_{\mathrm{DON}}$ during the wet period was not consistent between the two water years either ( $-35 \%$ vs. $29 \%)$. This lack of pattern complicates drawing any conclusion about factors driving stream DON dynamics between these two catchments. The DON pool in stream ecosystems is still poorly understood; yet, previous research acknowledges that it may be composed of a varying proportion of refractory and labile internally recycled DON (Brookshire et al., 2005; Lutz et al., 2012). The most recalcitrant fraction of DON may be intrinsically linked to DOC, so that $\mathrm{C}$ and $\mathrm{N}$ organic solutes may show similar patterns. That DON did not bear the pattern of DOC at either the hillslope or the valley-bottom catchments suggests that labile DON could account for a relevant proportion of the organic N pool at the FSW. Alternatively, differences between DOC and DON could respond to different terrestrial sources and different biogeochemical cycling in forest soils (Inamdar et al., 2008).

\section{Conclusions}

Stream water and solute export decreased substantially between the hillslope and valley-bottom catchments, especially during the transition period when environmental conditions were semiarid and hydrological connectivity between hillslope and valley bottom areas was likely the lowest. Spatial decoupling of nutrient concentration between hillslope and valley-bottom streams could reflect a distinct chemical signature of alluvial groundwater due to greater biogeochemical solute transformation at the alluvial riparian zone compared to hillslopes, and/or to mixing of past and present solute inputs into alluvial groundwater. The influence of the alluvial riparian zone on stream water and solute fluxes in semiarid catchments could increase, because climate change models predict more frequent drought periods in the future (IPCC, 2007), which could accentuate hydrological disconnection between hillslope and valley bottom areas and increase the length of stream water loss episodes. Our study contributes to the need of understanding the links between hydrology and nutrient cycling in ecosystems with limited water availability in order to anticipate how ecosystems in semiarid and in other regions of the world could respond to global warming. 
Acknowledgements. The authors thank A. Butturini for his support in the field. S. B. would like to thank E. Martí, F. Bartumeus, and J. W. Kirchner for insightful comments on an earlier version of the manuscript. This study was supported by a Spanish FPI grant (FPI 2001-0281) from the Spanish MCT, a Juan de la Cierva contract (JCI 2008-1777) from the Spanish MICINN, and funds provided by the Spanish CICT (REN 2001-3327 and MONTES-Consolider CSD-2008-00040).

Edited by: L. Pfister

\section{References}

Acuña, V., Giorgi, A., Muñoz, I., Uehlinger, U., and Sabater, S.: Flow extremes and benthic organic matter shapes the metabolism of a headwater Mediterranean stream, Freshwater Biol., 49, 960971, 2004.

Acuña, V., Giorgi, A., Muñoz, I., Sabater, F., and Sabater, S.: Meteorological and riparian influences on organic matter dynamics in a forested Mediterranean stream, J. N. Am. Benthol. Soc., 26, 54-69, 2007.

Bech, J. and Garrigó, J.: Algunes dades dels sòls de les castanyedes del Montnegre (Maresme), Diputació de Barcelona, Monografies, 24, 35-39, 1996.

Bernal, S. and Sabater, F.: The role of lithology, catchment size and the alluvial zone on the hydrogeochemistry of two intermittent Mediterranean- streams, Hydrol. Process., 22, 1407-1418, 2008.

Bernal, S., Butturini, A., Nin, E., Sabater, F., and Sabater, S.: Leaf litter dynamics and nitrous oxide emission in a Mediterranean riparian forest: implications for soil nitrogen dynamics, J. Environ. Qual., 32, 191-197, 2003.

Brookshire, E. N. J., Valett, H. M., Thomas, S. A., and Webster, J. R.: Coupled cycling of dissolved organic nitrogen and carbon in a forest stream, Ecology, 86, 2487-2496, 2005.

Burns, D. A., McDonnell, J. J., Hooper, R. P., Peters, N. E., Freer, J. E., Kendall, C., and Beven, K.: Quantifying contributions to storm runoff through end member mixing analysis and hydrologic measurements at the Panola Mountain Research Watershed (Georgia, USA), Hydrol. Process., 15, 1903-1924, 2001.

Butturini, A., Bernal, S., Sabater, S., and Sabater, F.: The influence of riparian-hyporheic zone on the hydrological responses in an intermittent stream, Hydrol. Earth Syst. Sci., 6, 515-526, doi:10.5194/hess-6-515-2002, 2002.

Butturini, A., Bernal, S., Nin, E., Hellin, C., Rivero, L., Sabater, S., and Sabater, F.: Influences of the stream groundwater hydrology on nitrate concentration in unsaturated riparian area bounded by an intermittent Mediterranean stream, Water Resour. Res., 39, 1110, doi:10.1029/2001WR001260, 2003.

Campbell, J. L. and Norman, J. M.: An introduction to environmental biophysics, 2nd ed. Springer-Verlag, New York, Inc., p. 281, 1998.

Cirmo, C. P. and McDonnell, J. J.: Linking the hydrologic and biogeochemical controls of nitrogen transport in near-stream zones of temperate-forested catchments: a review, J. Hydrol., 199, 88120, 1997.

Covino, T. P. and McGlynn, B. L.: Stream gains and losses across a mountain-to-valley transition: Impacts on watershed hydrology and stream water chemistry, Water Resour. Res., 43, W10431, doi:10.1029/2006WR005544, 2007.
Creed, I. F., Beall, F. D., Clair, T. A., Dillon, P. J., and Hesslein, R. H.: Predicting export of dissolved organic carbon from forested catchments in glaciated landscapes with shallow soils, Global Biogeochem. Cy., 22, GB4024, doi:10.1029/2008GB003294, 2008.

Detty, J. M. and McGuire, K. J.: Topographic controls on shallow groundwater dynamics: implications of hydrologic connectivity between hillslopes and riparian zone in a till mantled catchment, Hydrol. Process., 24, 2222-2236, 2010.

Fiebig, D. M., Lock, M. A., and Neal, C.: Soil water in the riparian zone as a source of carbon for a headwater stream, J. Hydrol., 116, 217-237, 1990.

Gordon, N. D., McMahon, T. A., and Finlayson, B. L.: Stream Hydrology, an introduction for Ecologists, New Jersey, PrenticeHall, 123 pp., 1992.

Hach, Co: Water Analysis Handbook, 2nd Edn., Hach Company, Loveland, CO, 1309 pp., 1992.

Hedin, L. O., von Fisher, J. C., Ostrom, N. E., Kennedy, B. P., Brown, M. G., and Robertson, G. P.: Thermodynamic constraints on nitrogen transformation and other biogeochemical processes at soil-stream interfaces, Ecology, 79, 684-703, 1998.

Heffernan, J. B. and Sponseller, R. A.: Nutrient mobilization and processing in Sonoran desert riparian soils following artificial rewetting, Biogeochemistry, 70, 117-134, 2004.

Helsel, D. R. and Hirsch, R. M.: Statistical methods in water resources. Studies in Environmental Science, 49, Elsevier Publishers, Amsterdam, p. 522, 1992.

Hill, A. R.: Nitrate removal in stream riparian zones, J. Environ. Qual., 5, 743-755, 1996.

Hill, A. R.: Stream chemistry and riparian zones, in: Streams and groundwaters, edited by: Jones, J. B. and Mulholland, P. J., Academic Press, San Diego, CA, p. 425 p, 2000.

Hill, A. R., Vidon, P. G., and Langat, J.: Denitrification potential in relation to lithology in five headwaters riparian zones, J. Environ. Qual., 33, 911-919, 2004.

Hinton, M. J., Schiff, S. L., and English, M. C.: The significance of storms for the concentration and export of dissolved carbon from two Precambrian Shield catchments, Biogeochemistry, 36, 67-88, 1997.

Hinton, M. J., Schiff, S. L., and English, M. C.: Sources and flowpaths of dissolved organic carbon during storms in two forested watersheds of the Precambrian Shield, Biogeochemistry, 41, 175-197, 1998.

Hooper, R. P., Aulenbach, B. T., Burns, D. A., McDonnell, J., Freer, J., Kendall, C., and Beven, K.: Riparian control of streamwater chemistry: implications for hydrochemical basin models Hydrology, Water resources and Ecology in Headwaters, Proceedings of the Head Water'98 Conference, Merano, Italy, IAHS Publ. no. 248, 1998.

Hornberger, G. M., Bencala, K. E., and McKnigth, D. M.: Hydrologic controls on dissolved organic carbon during snowmelt in the Snake River near Montezuma, Colorado, Biogeochemistry, 25, 147-165, 1994.

Inamdar, S. P. and Mitchell, M. J.: Hydrologic and topographic controls on storm-event exports of dissolved organic carbon (DOC) and nitrate across catchment scales, Water Resour. Res., 42, W03421, doi:10.1029/2005WR004212, 2006.

Inamdar, S. P., Rupp, J., and Mitchell, M.: Differences in dissolved organic carbon and nitrogen responses to storm-event and 
ground-water conditions in a forested, glaciated watershed in Western New York, J. Am. Water Resour. As., 44, 1458-1473, 2008.

Instituto Geológico y Minero de España (IGME): Mapa Geológico de España 1:50 000, Map 365, 38-15, Blanes, Madrid, Spain, 1983.

IPCC, Climate Change 2007: Synthesis Report. Contribution of Working Groups I, II and III to the Fourth Assessment Report of the Intergovernmental Panel on Climate Change, edited by: Pachaur, R. K. and Reisinger, A., IPCC, Geneva, Switzerland, p. 104, 2007.

Jencso, K. G., McGlynn, B. L., Gooseff, M. N., Wondzell, S. M., Bencala, K. E., and Marshall, L. A.: Hydrologic connectivity between landscapes and streams: Transferring reach- and plot-scale understanding to the catchment scale, Water Resour. Res., 45, W04428, doi:10.1029/2008WR007225, 2009.

Jencso, K. G., McGlynn, B. L., Gooseff, M. N., Bencala, K. E., and Wondzell, S. M.: Hillslope hydrologic connectivity controls riparian groundwater turnover: Implications of catchment structure for riparian buffering and stream water sources, Water Resour. Res., 46, W10524, doi:10.1029/2009WR008818, 2010.

Keeney, D. R. and Nelson, D. W.: Nitrogen inorganic forms, in: Methods of Soil Analysis, Part 2. Chemical and microbiological properties edited by: Page A. L., Agronomy Monographs 9, AASSSA Publisher, 643-698, 1982.

Lutz, B. D., Bernhardt, E. S., Roberts, B. J., Cory, R. M., and Mulholland, P. J.: Distinguishing dynamics of dissolved organic matter components in a forested stream using kinetics enrichments, Limnol. Oceanogr., 57, 76-89, 2012.

Martí, E., Grimm, N. B., and Fisher, S. G.: Pre- and post-flood retention efficiency of nitrogen in a Sonoran Desert stream, J. N. Am. Benthol. Soc., 16, 805-819, 1997.

Martí, E., Fisher, S. G., Schade, J. J., and Grimm, N. B.: Flood frequency and stream-riparian linkages in arid lands, in: Streams and Groundwater, edited by: Jones, J. B. and Mulholland, P. J., Academic Press, San Diego, CA, p. 425, 2000.

McGuire, K. J. and McDonnell, J. J.: Hydrological conectivity of hillslopes and streams: characteristic time scales and nonlinearities, Water Resour. Res., 46, W10543, doi:10.1029/2010WR009341, 2010.

Meixner, T. and Fenn, M.: Biogeochemical budgets in a Mediterranean catchment with high rates of atmospheric $\mathrm{N}$ depositionimportance of scale and temporal asynchrony, Biogeochemistry, 70, 331-356, 2004.

Meixner, T., Huth, A. K., Brooks, P. D., Conklin, M. H., Grimm, N. B., Bales, R. C., Haas, P. A., and Petti, J. R.: Influence of shifting flow paths on nitrogen concentrations during monsoon floods, San Pedro River, Arizona, J. Geophys. Res., 112, G03S03, doi:10.1029/2006JG000266, 2007.

Meyer, J. L., Wallace, J. B., and Eggert, S. L.: Leaf litter as a source of dissolved organic carbon in streams, Ecosystems, 1, 240-249, 1998.

Morrice, J. A., Valett, H. M., Dahm, C. N., and Campana, M. E.: Alluvial characteristics, groundwater-surface water exchange and hydrological retention in headwaters streams, Hydrol. Process., 11, 253-267, 1997.

Mulholland, P. J.: Regulation of nutrient concentrations in a temperate forest stream: roles of hillslope, riparian and instream processes, Limnol. Oceanogr., 37, 1512-1526, 1992.
Pacific, V. J., Jencso, K. G., and McGlynn, B. L.: Variable flushing mechanisms and landscape structure control stream DOC export during snowmelt in a set of nested catchments, Biogeochemistry, 99, 193-211, 2010.

Peterjohn, W. T. and Correll, D. L.: Nutrient dynamics in an agricultural watershed: observations on the role of a riparian forest, Ecology, 65, 1466-1475, 1984.

Pinay, G., Ruffinoni, C., and Fabre, A.: Nitrogen cycling in two riparian forest soils under different geomorphic conditions, Biogeochemistry, 30, 9-29, 1995.

Piñol, J., Lledó, M. J., and Escarré, A.: Hydrological balance of two Mediterranean forested catchments (Prades, northeast Spain), Hydrol. Sci., 36, 95-107, 1991.

Romano, J. and Krol, J.: Capillary ion electrophoresis, and environmental method for determination of anions in waters, J. Chromatogr., 640, 403-412, 1993.

Seibert, J., Grabs, T., Köhler, S., Laudon, H., Winterdahl, M., and Bishop, K.: Linking soil- and stream-water chemistry based on a Riparian Flow-Concentration Integration Model, Hydrol Earth Syst. Sci., 13, 2287-2297, doi:10.5194/hess-13-22872009, 2009.

Strahler, A. N. and Strahler, A. H.: Geografía física, 3rd Edn., Omega, Barcelona, Spain, 636 pp., 1989.

Technicon: Technicon Instrument System, Technicon Method Guide, Tarrytown, NY, 1976.

Triska, F. K., Duff, J. D., and Avanzino, R. J.: The role of water exchange between a stream channel and its hyporheic zone in nitrogen cycling at the terrestrial-aquatic interface, Hydrobiologia, 251, 167-184, 1993.

UNEP: World Atlas of Desertification, London, Edward Arnold, 69 pp., 1992.

Valderrama, J. C.: The simultaneous analysis of total nitrogen and total phosphorus in natural waters, Mar. Chem., 10, 87-117, 1981.

Valett, H. M., Morrice, J. A., Dahm, C. N., and Campana M. E.: Parent lithology, surface-groundwater exchange, and nitrate retention in headwater streams, Limnol. Oceanogr., 41, 333-345, 1996.

Valett, H. M., Dahm, C. N., Campana, M. E., Morrice, J. A., Baker, M. A., and Fellow C. S.: Hydrologic influences on groundwatersurface water ecotones: Heterogeneity in nutrient composition and retention, J. N. Am. Benthol. Soc., 16, 239-247, 1997.

Valett, H. M., Baker, M. A., Morrice, J. A., Crawford, C. S., Molles Jr., M. C., Dahm, C. N., Moyer, D. L., Thibault, J. R., and Ellis, L. M.: Biogeochemical and metabolic responses to the flood pulse in a semiarid floodplain, Ecology, 86, 220-234, 2005.

Vázquez, E., Romaní, A. M., Sabater, F., and Butturini A.: Effects of the dry-wet hydrological shift on dissolved organic carbon dynamics and fate across stream-riparian interface in a Mediterranean catchment, Ecosystems, 10, 239-251, 2007.

Vidon, P. and Hill, A. R.: Denitrification and patterns of electron donors and acceptors in eight riparian zones with contrasting hydrogeology, Biogeochemistry, 71, 259-283, 2004a.

Vidon, P., and Hill, A. R.: Landscape controls on the hydrology of stream riparian zones, J. Hydrol., 292, 210-228, 2004b.

Walsh, T. W.: Total dissolved nitrogen in seawater: a new high temperature combustion method and a comparison with photooxidation, Mar. Chem., 29, 295-311, 1989. 